sciendo

LEGE ARTIS

Language yesterday, today, tomorrow

Vol. III. No 22018

\title{
SPEECH ACT OF THREAT IN EVERYDAY CONFLICT DISCOURSE: PRODUCTION AND PERCEPTION
}

\author{
Nikita Probst*, Immanuel Kant Baltic Federal University, Kaliningrad, Russia \\ Tatiana Shkapenko, Immanuel Kant Baltic Federal University, Kaliningrad, Russia \\ Arina Tkachenko, Immanuel Kant Baltic Federal University, Kaliningrad, Russia \\ Alexey Chernyakov, Immanuel Kant Baltic Federal University, Kaliningrad, Russia \\ *Corresponding author
}

Probst, N., Shkapenko, T., Tkachenko, A. \& Chernyakov, A. (2018). Speech act of threat in everyday conflict discourse: Production and perception. In Lege artis. Language yesterday, today, tomorrow. The journal of University of SS Cyril and Methodius in Trnava. Warsaw: De Gruyter Poland, 2018, III (2), December 2018, p. 204-250. DOI: 10.2478/lart-2018-0019 ISSN 2453-8035

\begin{abstract}
The article explores pragmasemantic aspects of the speech act of threat (SAT) in everyday conflict discourse, using examples from Russian colloquial speech. The authors analyze the impact of direct and indirect threats on the addressee from the point of view of the theory of speech acts, biopsychology, and physiology, which makes it possible to understand the nature of SATs and identify the key communicative and semantic factors of this type of speech acts.
\end{abstract}

Keywords: pragmalinguistics, theory of speech acts, speech act of threat, directive speech act, commissive speech act.

\section{Introduction}

It is well known that everyday communication reflects the diversity of real-life experiences of the individual and society. In this connection "basic methods of organizing and classifying forms of knowledge at all levels of human cognition, and their manifestation in everyday life communication scenarios are of considerable interest" (Романова 2009: 178). Various conflict situations, which "result from continuous inconsistencies in the opinions and interests of individuals as they 
communicate" (Chen \& Tseng 2016; Curseu et al. 2012; Kaushal \& Kwantes 2006; Rahim 2015) are parts of this type of communication. To achieve their goals, interlocutors can use a wide range of language means, including the speech act of threat (SAT). This speech act "may loosely be defined as a form of expression that communicates that some undesirable state of affairs (physical injury, for instance) may or will befall the recipient or a third party as a consequence of another's purposeful actions" (Watt et al. 2013: 99).

Research works devoted to the study of SAT usually focus on its classification from the point of view of the theory of speech acts, or the ways of representation in a particular language (Жучков 2009; Мартынова 2006; Nicoloff 1989; Novoselova et al. 2015; Wunderlich 1976). In other words, these works mainly focus on such issues as (i) what a threat as a speech act is and (ii) how it is realized in speech. We, however, stand that there is a number of questions that have not been adequately covered:

1) How does a threat affect the recipient?

2) What is the nature of SAT communicative effectiveness?

3) Why do interlocutors sometimes prefer to express a threat directly, whilst in other cases they opt for an indirect speech act that conforms to all norms of social etiquette, etc.?

To answer these questions, there is a need for a comprehensive study of SATs, which will employ not only the means of classical linguistics, but also those of psychology and physiology.

This research aims to study the key aspects of threat as a special speech act and to establish the key criteria for determining its communicative effectiveness.

The research objectives of this study are as follows: to consider the functional and semantic nature of a SAT in the light of the theory of speech acts; to explore the 
specifics of SAT perception from the perspective of biopsychology, psychology, and physiology; to identify the key success criteria for a SAT; to demonstrate the peculiarities of the use of direct and indirect SATs in everyday conflict discourse, using segments of Russian feature films as examples; to analyze the effectiveness of the direct and indirect forms of a SAT in the chosen type of discourse.

Thus, the article will be interesting for researchers who study both common and peculiar features of speech acts as well as their perception in various cultures.

\section{Methods of research and research material}

The following methods were used in the analysis of SATs:

1) general research methods such as deduction, induction, analysis, and synthesis;

2) functional and semantic analysis, which allows us to establish the main content features of the considered type of speech acts;

3) method of interpretation, which allows us to demonstrate the various aspects of production and perception of SATs, using the illustrative material presented in the article;

4) simulation method that serves to disclose and confirm individual conclusions concerning the functioning of SATs in speech.

A comprehensive study of the specific features of SATs in everyday conflict discourse requires a complex approach that combines linguistic research methods with the data obtained in biopsychology and physiology.

\section{The act of threat in conflict discourse}

Conflict discourse is an interactive (dialogical) type of discourse, characterized by the implementation of anti-ethical goals (i.e. an affront, harassment, coercion to something, etc.), which contradict the inherently positive nature of communication and leads to communicative disruptions and even breaks in communication (Каразия 2006: 78). This discourse type has received wide coverage in research literature, with focus 
on cultural, ethnic, and individual aspects (Perelmutter 2018; Smith 1997 and others), as well as on the structure and elements of conflict discourse as such (Каразия 2006; Садыкова 2005; Сейранян 2016; Шкапенко \& Вертелова 2018 and others).

The phenomenon of conflict has been more or less characteristic of any society throughout the history of humankind. It is an interpersonal collision, varying in its forms of expression, power of manifestation, duration, and severity. Conflict situations may be caused by different factors (a clash of personal interests, a different point of view on a particular issue, antisocial behavior of one of the interlocutors, etc.), but they always imply a clash of interests or intentions of two or more people. At the same time, the speaker can pursue various goals: to force the addressee to act in a certain way, to prevent an action, to follow a specific line of behavior, to bring the addressee to a certain psychological state, etc. In order to achieve these goals, "a speaker may even employ a communicative strategy that deliberately creates social conflict with the addressee, thus causing disharmony between the interlocutors" (Limberg 2009: 1376). The most important element of this strategy is the use of direct and indirect forms of threat. In this connection, it seems appropriate to consider speech acts of menace in conflict discourse.

A number of scholars (Анцупов \& Шипилов 2000; Рубин 2001; Сейранян 2016) consider a SAT as a severe conflict tactics aimed at causing psychological harm and damage to other participants of communication. Speech acts of this type, apart from imposing certain requirements, instructions, orders, ultimata, etc., are based on the creation of a threat to the 'I-concept' of the addressee and to their self-esteem. The pressure on the addressee in such cases is exerted with the help of fear or guilt, which are evoked directly, or self-doubt, which is caused indirectly by the threat producer (Сейранян 2016: 63). 


\section{Speech act of threat in pragmalinguistics}

The speech act of threat (SAT) has been thoroughly studied in pragmalinguistics. Different researchers equal SATs with taboo verbal acts and describe them as purposefully destructive behavior (Апресян 2003; Мартынова 2006; Brown \& Levinson 2009; Leech 1983; Ohm \& Thompson 2004 and others). Linguists have been researching a whole range of issues, including the pragmatic nature of a SAT (Жучков 2010; Мартынова 2006; Nicoloff 1989; Wunderlich 1976 and others), the structure of a SAT (Жучков 2009; Novoselova et al. 2015), its functions in discourse (Новоселова 2013; Романов 1988 and others), and various speech tactics and strategies (Чесноков 2015; Эпштейн 2008 and others).

However, there is no universally accepted understanding of the communicative and semantic nature of threat. In many respects, this is determined by the specificity of this type of speech act due to the existing social, ethical, and linguistic norms of communicative performance (Жучков 2009: 70; Searle 1979: 7). In many related research works, the functional and semantic content of structures expressing threat (or speech acts that are functionally and semantically close to them) is usually considered from the point of view of two meanings:

1) the commissive meaning, realized in the speaker's intention to implement a negative action for the addressee (Жучков 2010; Почепцов 2001; Austin 1962; Cartwright 1984; Searle 1975; Wunderlich 1976 and others);

2) the causative (directive) meaning, realized in the speaker's desire to compel the addressee to a certain action or, conversely, to abstain from it, that can have adverse consequences for the addressee (Вежбицка 1985; Вендлер 1985; Маслова 2007; Новоселова 2013 and others).

In our opinion, a threat as a speech act, judging by its functional orientation, should primarily be attributed to directives, and not commissives. As Nicoloff notes (1989: 503): 
"Threatening someone verbally can be analyzed as $S$ (speaker) saying something to A (addressee) in order to get A to think that $S$ is going to cause harm to A, with the purpose of (a) frightening A; $(b)$ thereby getting $A$ to do as $S$ wishes. This is a fairly exhaustive description of a verbal threat, which may correspond to most people's conception of the action. It is wide enough to encompass both overt and covert threats (owing to its use of the predicate 'get-to-think')".

In this case, we understand inducement in a broad sense: not only as a means of compelling the interlocutor to a certain action, but also as a tool enabling the speaker to adjust the addressee's behavior and to control their emotional state.

The speech act of threat occupies a special place among other directives due to its peculiar functional semantic structure. Zhuchkov considers menacing statements that combine the illocutionary features of commissives and directives as complex speech acts, which represent an indirect inducement (Жучков 2009). Leaving open to question the assumption on the indirect nature of threat in the realization of the performative intention, we, however, completely share the opinion of the researcher on its complex structure. Moreover, we hold that both the commissive and the performative elements of the SAT are integral parts of any threat. Given the absence of one of the abovementioned elements in the semantic field of the considered constructions, this act turns into either a typical directive (prescriptive) or a commissive speech act. In other words, we can talk about a binary content paradigm of the SAT (the first part is an imperative; and the second is a promise of punitive actions). For example, when parents tell their child, "If you don't behave, you'll be put in the naughty corner!", the threat contains both an imperative (stop misbehaving) and a promise of punishment (will be on time out).

There are some differences between SATs and commissives. Following Searle, we define commissives as "illocutionary acts whose point is to commit the speaker (again in varying degrees) to some future course of action" (1979: 14), i.e. the producer of the message is in the focus of the corresponding speech acts. The producer of threat must commit a certain action (X), and must behave according to the expected behavioral model. At the same time, a SAT even with no directive component is aimed at the 209 
addressee: he/she has either to do X, or to adhere to a certain behavior:

One crucial distinction between promises on the one hand and threats on the other is that a promise is a pledge to do something for you, not to you, but a threat is a pledge to do something to you, not for you. A promise is defective if the thing promised is something the promisee does not want done; and it is further defective if the promisor does not believe the promisee wants it done, since a non-defective promise must be intended as a promise and not as a threat or warning (Searle 1969: 58).

Sami (2015: 50) points another difference between the two acts:

In the case of threats, if the issuer of the act were back down the target then has no stimulate to induce the issuer to carry out the threat. In case of promises, the target wants the issuer to respect the promise. Moreover, the differences can be shade on lost and gain. Threats, for instance, focus on what the target has to lose and invoke a loss frame that encourages resistance. Whereas, promises focus on what recipient can gain and, thus, frames the interaction as a potential gain and encourages acceptance of the proposal.

In a SAT, the very communicative goal of it as a commissive act - assuming the obligation to perform an action - is false since it is not a priority for the addressee of the relevant act. As Novoselova writes,

"The initiator of a threat of menace does not consider it to be solely his communicative intention, since referring to SAT as an act of inducement under the fear of punishment, the speaker wants to influence ... his [addressee's] emotional state in order to make him perform certain actions" (Новоселова 2013: 10).

Some researchers (e.g., Salgueiro) point to another aim of threat - the assertion of one's strength, power over the speaker, or implying possible vengeance for something:

"In a typical example, a bully utters elementary threats just to show off or display his or her power, without the immediate receiver having done or shown signs of doing anything to warrant such a threat. Another kind anticipates vengeance: An act of vengeance is threatened in a speech act that, at the same time, constitutes an attempt to initiate vengeance by making the receiver suffer in anticipation of the threatened act" (2010: 216).

However, we believe that even when the speaker threatens to kill the addressee or to cause bodily harm, in most cases this is just an attempt to manipulate the addressee: to 
intimidate him/her, to impose the role of a victim, to break his/her will, and to use the state of depression and fear in the future.

\section{Biopsychological and physiological perception mechanisms of SAT}

Currently, according to our observations, there are no large-scale interdisciplinary studies covering all the aspects of the producing and perception of SAT - linguistic, communicative, psychological, and physiological. Meanwhile, the study of linguistic facts from the suggested perspective makes it possible to understand the very nature of language as a mode of communication, complex cognitive processes, the development of human personality, and ethnos.

As Karasik points, "Every speech act - whether it is truly unique or not - is a tiny drop in a continuously moving stream of human experience. In this capacity, the speech act absorbs and reflects a unique combination of circumstances, under which and for which it has been created" (Карасик 2000: 39). Thus, a purely linguistic approach is not enough to fully understand the mechanisms of production and perception of a SAT in any discourse and to identify the conditions, under which it can be used with maximum efficiency.

It is common knowledge that production and perception of speech have an impact on the individual and initiate a whole complex of cognitive, psychological, and physiological processes. It is impossible to adequately study the nature of the most complex mechanisms of speech (including acts of threat) production and perception without understanding the essence of the latter.

According to a number of scholars in the field of biopsychology (Carver \& White 1994; Gray 1987; Greenberg et al. 2003; Jonas et al. 2014), responses to various threatening signals are directly related to the Behavioral Inhibition System (BIS). This system, along with the Behavioral Activation System (BAS), is a constructive element of the 
biopsychological theory of personality, developed by Gray (1987). The BIS responds to incentives for punishment, and initiates avoidance behavior and a subjective sense of anxiety.

Threats have a direct effect on the BIS and evoke several BIS-related phenomena such as potential for anxiety (Greenberg et al. 2003), a sense of lacking control (Fritsche et al. 2011), personal uncertainty (Van den Bos et al. 2005), or anxiety (McGregor et al. 2010). Obviously, SATs cause negative psychological reactions in the addressee.

Threat does not only suppress the addressee's will; it also activates another process, analyzed by Jonas, McGregor, and other researchers. In their opinion, threatening speech acts "essentially involve discrepancies that activate alarm cues that can culminate in anxious arousal to which people immediately respond with a variety of proximal reactions related to attentional vigilance and avoidance motivation" (2014: 229).

It seems quite natural that, having faced a threat to their life, health, well-being, etc., the addressee of the imperative impact feels a psychological and physiological urge to avoid unpleasant or dangerous situations. The addresser of the threat, actually 'prompts' the addressee the correct (or even the only) way to fulfill the will of the speaker.

To some extent, feelings of anxiety, self-doubt, loss of control over one's emotions, etc. - all these biopsychological factors are associated with fear. The importance of this emotion as one of the inherent survival mechanisms is difficult to overestimate. As Jing-Schmidt and Kapatsinski noted, "Despite controversies in psychology as to which emotions are basic, the recognition of fear as a basic emotion is unequivocal. Part of being alive is being afraid" (2012: 347). This is quite natural, because "fear is a remarkably adaptive behavioral response, allowing us to predict, react, and adjust to past, present, and future threats" (Dymond et al. 2015: 51). However, despite the fact 
that fear as a biological mechanism increases the individual's chances of survival, this emotional state is a destabilizing factor of their behavior, adversely affecting the ability to resist negative external factors. Moreover, some psychologists say that at the current stage of biological evolution, the negative effects of fear are significantly stronger:

"The study of the physiology and neurochemistry of fear allowed researchers to better understand the biological mechanisms of human behavior. The individual has to deal with the many social and cultural norms, in the light of which genetic instincts lose their adaptive significance or may even ruin a person's life. In this regard, fear that triggers the fight or flight reaction, which was very effective during the period of biological evolution, produces completely different effects in modern life. It may cause a constant feeling of tension, insecurity, and inability to realize one's potential. Fear limits the individual's activity, and in some cases literally paralyzes him/her. The chronic state of anxiety and fear leads to various psychosomatic illnesses" (Щербатых \& Ноздрачев 2000).

That is why the imperative intention of SATs is realized by appealing to the feeling of fear in the addressee. In fact, the one who threats strives for initiating the psychophysiological reactions, associated with fear. However, to reach this goal, the threat producer needs to "find the optimal leverage over the addressee" (Жучков 2010: 9) by threatening, for instance, to destroy the addressee's life, to cause harm to their health or property, etc. At the same time, in the process of communication, the threat producer, as Zhuchkov points out, can try to direct his threat precisely to what is most important for the addressee in the given situation of communication. Alternatively, the speech act producer may project his/her own fears on the addressee; and to choose the kind of potential damage in accordance with what seems most undesirable to himself/herself (ibid.).

\section{Communicative and semantic factors of SAT effectiveness}

The ultimate goal of any act of threat is achieved only if the addressee may be punished for not performing the action in question, or, in the case of an indirect threat, if the punishment is implied. In this regard, the key communicative and semantic factors that determine the force of the motivating impact of a SAT (irrespective of whether it is direct or indirect) include the following ones: 
1. The significance of punitive measures, implied by a SAT, for the addressee.

If the actions that the speaker promises to take as punishment for the disobedience do not threaten the addressee with the loss of something that is important to him/her, the threat is no longer effective. For example, it makes no sense for one of the spouses to threaten the other with a divorce, if the threat does not produce any effect.

2. The actual possibility of punishment designated or implied by the threat producer for the non-fulfillment of the causal action.

By this criterion, we mean a whole complex of physical, mental, and material resources available to the threat producer and necessary for the realization of the threat. For example, if a seven-year-old child with a toy gun in his hands is threatening to kill an adult, such a speech act is not communicatively successful. However, the communicative perspective of a similar statement can be quite different if the threat producer is an adult criminal, armed with real weapons.

\section{High probability (inevitability) of negative actions stated or implied by the SAT producer}

The availability of means and opportunities for the execution of a threat does not necessarily mean that it will be executed in reality. As we mentioned above, the threat realization is not always in the interests of the threat producer, and the addressee can be aware of that. For example, if during a family fight the husband - in order to make his wife silent - threatens her with physical abuse, he may still execute his threat: he is physically stronger, the spouses are in their own home, no one can witness the abuse or defend the wife, etc. At the same time, there are a number of factors that make it unsafe for the bully: the prospect of a divorce causing moral and material damage, the risk of being reported to the police, public condemnation, etc. The higher the significance of these factors for the producer of the threat, the lower the probability of disobedience of the addressee of the SAT. If the addressee of the speech act is aware of the significance of these 'hampering' factors for the speaker, the communicative 
success of the act of threat may be null.

If a SAT meets all the criteria listed above, the threat producer can expect the fulfillment of his/her will. However, the correspondence of the implied punishment to the last two factors does not necessarily have to be real: it is enough to convince the addressee of the possibility of punishment. The converse is also true: if the threat producer has all the necessary resources to fulfill the threat and is ready to 'go to the end' realizing their aggressive intentions but is not able to make the addressee believe it, the communication success of a SAT may not be achieved. In this regard, we hold that there is another factor of the SAT effectiveness - the rhetorical persuasiveness of the speech impact. This factor stipulates that the SAT engages the totality of external verbal (a corresponding set of lexical means, a particular construction of a phrase, etc.) and non-verbal (intonation, posture, glance) signs indicating the speaker's ability and readiness to harm the addressee. In other words, the SAT effectiveness factor can be viewed as a peculiar variant of the implementation of Grice's maxim of quality, suggesting that the speaker does not give information that is false or that is not supported by evidence (Grice 1975: 47).

These criteria are relevant for both direct and indirect forms of the analyzed type of menacing acts.

\section{The analysis of SAT in everyday conflict discourse}

\subsection{Research material}

This research is based on the analysis of segments of Russian feature films, which contain different types of SATs in everyday conflict situations. The choice of this research material is not accidental.

Firstly, feature films mirror everyday communication. They "do have an important tie to reality, and that tie consists in how they can show us the world in a way that other 
art forms cannot" (Fiorelli 2016: 8). In spite of the fact, that characters' speech in feature films, including those based on actual events, is viewed as a special text, 'not solely the province of screenwriters' but the collective product of directors, editors, sound specialists, actors and so forth" (Kozloff 2000: 122), we completely agree with Piazza's idea that cinematographic communication is based on real models of discourse:

"Although film dialogue is fictitious, it can be assumed, in so far as the final result of the invisible process of writing behind a film script is spoken discourse, that real-life dialogue is the template behind it. Thus dialogue in cinema aims to reproduce the interactional mechanisms found in everyday exchanges" (2006: 2087).

Secondly, for obvious reasons, showing a domestic conflict or a crime in reality, as well as their modelling in experiments, presents a number of difficulties. In this respect, feature films, which reflect a diversity of SAT situations, are an optimal selection of material. Therefore, movie segments from Russian feature films are suitable material for our research.

For this study, we selected and analyzed 14 contemporary (the year of production varies from 1993 to 2017) full-length Russian feature films. The selection was made according to the following criteria:

1) authenticity of the language (the same expressions are used in modern everyday communication);

2) the presence of scenes, which reflect conflict communicative situations that are more or less typical of contemporary Russia.

When selecting the research material, preference was given to films belonging to the genres of drama, criminal drama, melodrama, and lyrical comedy. The method of continuous sampling allowed us to pick 19 video segments. This article presents four video segments from four different films, which most authentically reflect the key features of SATs. The English translation of the language material presented in the 
video segments was done independently and exclusively for research purposes. At the same time, we take into account that "if the audience's cultural background is other than that envisaged by the original communicator, i.e. when the translator is "quoting the original 'out of context'" (Fedoriv 2016: 14), a communication attempt of the characters from Russian feature films may not be obvious for non-Russian speakers. However, even though all the examples are taken from Russian feature films and are in Russian, we stand that our observations and conclusions are largely relevant to both Russian and international research community.

It is common knowledge that there are ethnic, cultural, and linguistic differences between cultures, and yet, the fundamental human psychological and physiological mechanisms are universal. It allows us to assume the existence of similar mechanisms of perception and production of SATs.

\subsection{Direct threat}

According to Chesnokov, direct threats are

"statements, made by the subject of speech, openly expressing their intention to punish the addressee in case the latter feels reluctant to obey or actually does not obey certain norms of behavior imposed by the aggressive speaker, provided the latter openly states his/her intention to cause harm" (Чесноков 2015: 132).

In such acts, "the speaker and/or other people acts as a punitive force and predicts a) aggressive actions aimed at alienating the object of threat from the speaker and/or from the group the addressee belongs to, causing moral and/or physical harm; b) speech acts indicating that the speaker or the group of people he/she is part of, will definitely implement the negative punitive measures against the addressee" (Чесноков 2015: 132). The explicit character of direct threat means that the speaker shows the addressee what he/she wants, and a possible punishment following disobedience. This kind of threats is formulated in a direct and unequivocal way, including the verbal and nonverbal communication tools of different types. 
Such threats can be implemented by resorting to verbal means, affecting the addressee's mental and psychological state (the action required and the possible punishment are clearly pronounced). The task of the producer of the SAT in this case is to quickly intimidate the interlocutor, promising to kill / maim / humiliate, etc. him. We refer to such menacing SATs as direct verbalized threats. Figure 1 (Thief 1997) illustrates this type of threat. In the film segment below, the film's hero covers up for his woman's son, whom a neighbor decided to teach a lesson for his aggressive behavior towards other children (ignoring the fact that this kind of aggression was a response to the beating that the boy suffered a few minutes ago).

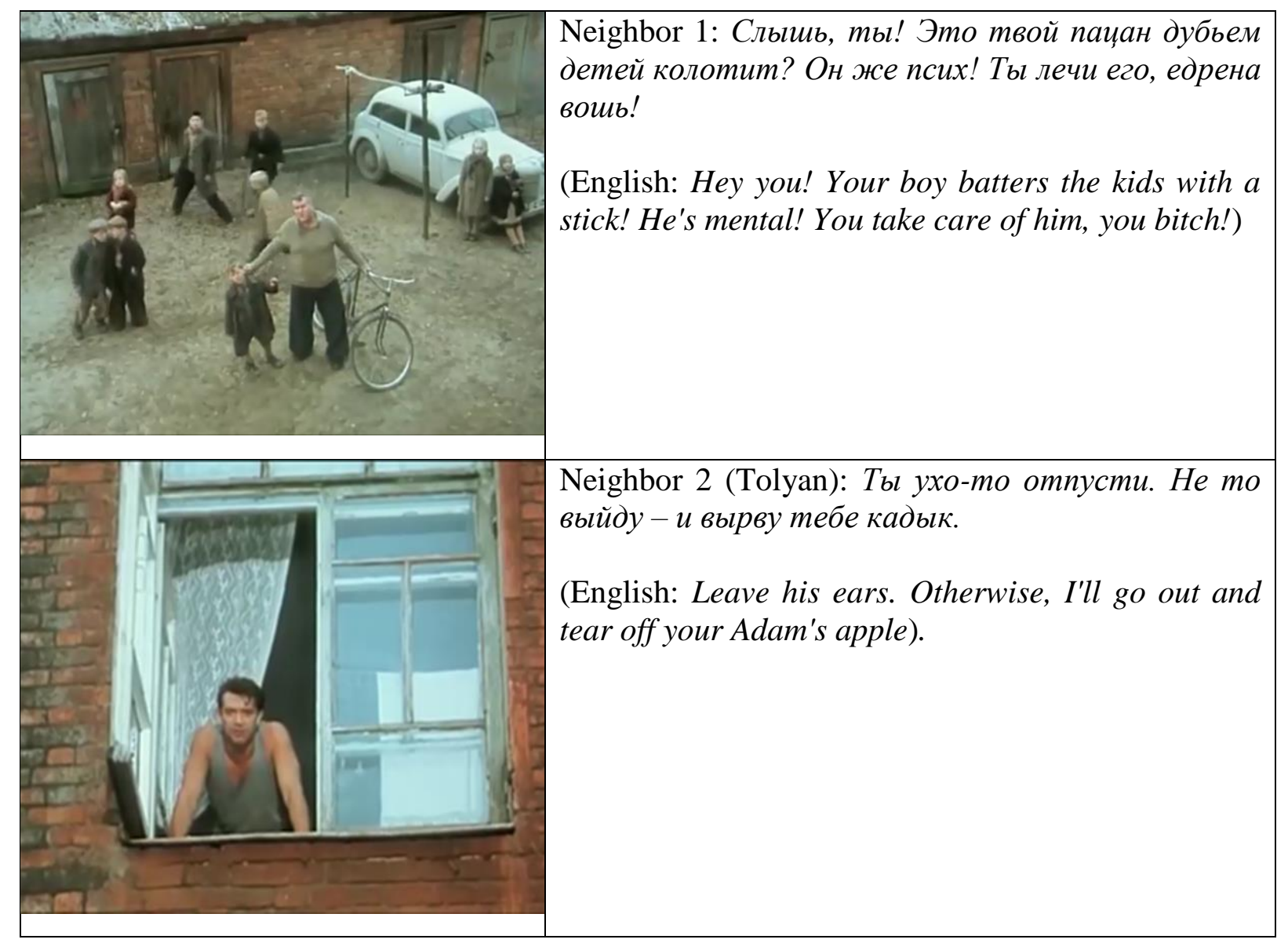

Figure 1. Directly verbalized threats

Screenshots (taken by the author) from the film "The thief". Available at: https://www.youtube.com/watch?v=1MGvFJkME7c\&t=3s 
In this example, there is a pronounced imperative (Ухо-то отпусти / Leave his ears), and a promise of punishment (Не то выйду - и вырву тебе кадык / I'll go out, and tear off your Adam's apple). The recipient of the SAT is motivated by the following factors: appealing to the instinct of self-preservation of the addressee (a reference to such vital values as life and health); and intensification of the threatening effect by specifying the form of physical abuse (tearing his Adam's apple), which is definitely very painful and may turn lethal.

In the latter case, it is necessary to take into account the extra-linguistic specificity of this commissive. It is determined by the fact that this kind of violence in the Soviet Russia was more characteristic of the representatives of the marginal strata of the population - primarily of criminals. Therefore, the assumption that the sender of such a threat can be socially dangerous, a repeated criminal, can have an additional deterrent effect.

In addition, the manner of voicing the threat is rather peculiar: the sender speaks in a calm manner, does not raise his voice, his face and eyes show confidence. Theoretically, it should produce a certain impression on the addressee.

From the point of view of communicative effectiveness, this threat can be qualified as serious enough, but not entirely convincing as we can see from the subsequent events in the film. This threat is serious because the sender of a menacing message threatens the addressee with serious punitive measures and has a real possibility of carrying out his threat (the speaker is a young and physically strong man, able to really 'tear off somebody's Adam's apple'). However, the addressee (neighbor) does not regard it as sufficiently serious to perform the causal action. However, the addressee (neighbor) does not regard it as sufficiently serious to perform the causal action for the following reasons: 
a) a low probability of the threat from the neighbor's point of view, which is determined by two factors: i) the physical supremacy of the threat producer compared to the addressee is not obvious, since the addressee is also physically strong; ii) the context of the situation is not suitable for the implementation of the announced threat (to tear off someone's Adam's apple during the day, in the yard, with many witnesses is unreasonable; it is a crime which has to be prosecuted);

b) the cruelty of the promised punishment, apparently, is perceived by the addressee as an exaggeration, impossible under the current circumstances since he does not know that the speaker is a career criminal for whom the commission of such an act is not something extraordinary). In other words, the threat is perceived by the addressee as a non-convincing attempt of intimidation.

Thus, the sender's menacing utterance does not meet the criteria of inevitability and rhetorical persuasiveness of the threat. As a result, the speaker suffers a communicative failure and is compelled to resort to an additional measure of intimidation - physical coercion: he goes out into the yard, beats his victim, and damages his property (a bicycle). After confirming his dominant status (along with, therefore, the possibility and inevitability of the fulfillment of his promise), he threatens the addressee again (Figure 2).

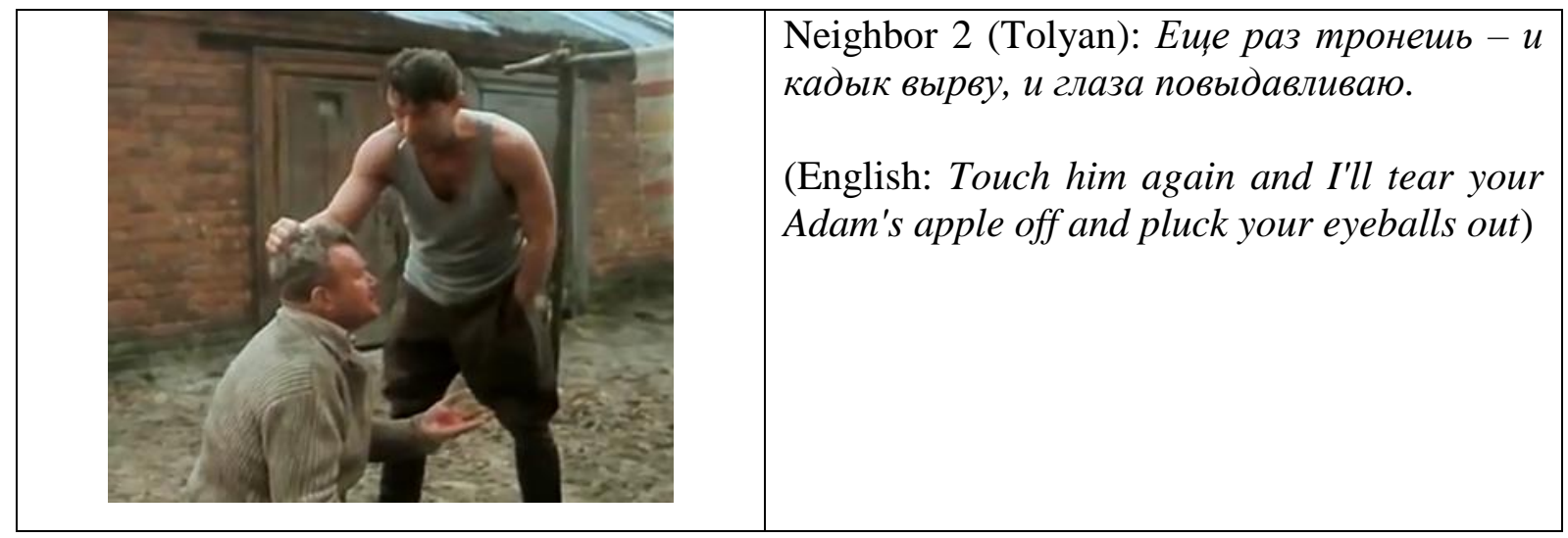

Figure 2. An additional (physical coercion) measure of intimidation as a result of communicative failure. Screenshots (taken by the author) from the film "The thief". Available at https://youtu.be/1MGvFJkME7c?t=1m2s 
It should be noted that in everyday conflict discourse, the need for a 'physical' confirmation of threat (which manifests in a variety and intensity of aggressive moves - a push, a punch, etc.) in communication between same-sex interlocutors (usually men) is a common phenomenon. Consequently, in such situations, the one who implements the act of threat must have a certain set of means that ensure, from the point of view of the addressee, a high probability of its execution (physical strength, availability of weapons, a certain social status, etc.).

The elements of the threat content paradigm (i.e. its commissive and directive parts) are not always verbalized. This can be explained by the fact that in everyday discourse (and in any language) the promise of harm (as well as any other communicative act) can be expressed both verbally and non-verbally by intonation, facial expressions, gestures, posture, position of the speaker, etc. (Mehrabian \& Wierner 1967; Zamfir 2017). It should also be noted that in oral communication interlocutors use verbal and non-verbal means in the following proportion: $7 \%$ words, 30\% paralanguage, 55\% other elements of non-verbal communication (Mehrabian 1968). Yet, resorting to these means in conflict discourse does lead to a conclusion about an indirect character of the corresponding SAT. For instance, it is difficult to interpret a punch in a dark alley as an implicit means of representing a threat commissive - even though this speech act was preceded by a rather polite request to lend the juvenile criminal a small sum of money.

In any type of discourse non-linguistic means are important, self-explanatory tools for conveying a variety of senses. In the case of SATs, non-verbal means are often the main indicators of the author's intention for the addressee, showing him/her that the speech act contains not just a requirement (which can be ignored), but also a directive, which can have serious consequences, if ignored. At the same time, the motivating effect, causing the addressee's anxiety or fear, may even have a more serious psychological impact than a verbalized promise of threat. When the addressee 
understands the intention of the speaker to act aggressively and cause bodily harm (through intonation, facial expressions, and gestures that are usually 'read' without any difficulty by any socially adapted individual), this can act stronger than a simple declaration. Consequently, menacing directives, the commissive part of which is expressed by a complex of obviously aggressive and explicit non-verbal means (an aggressive facial expression; a posture, convenient for attack, etc.), can be classified as direct SATs. Such acts can be called direct threats with non-verbalized elements of the content structure. Figure 3 (The brother 1997) can serve as an illustration of this type of threat. The main character (Danila Bagrov), while staying at his girlfriend's (Svetlana's) flat, meets her husband (Pavel Evgrafovich), who comes home while his wife is away. Danila knows about a serious problem in their marriage - the husband regularly beats his wife. After a short conversation, Danila asks Svetlana's husband in a threatening way to disappear from her life. The corresponding dialogue is presented below (the threat is shown in Screenshot $d$ ):

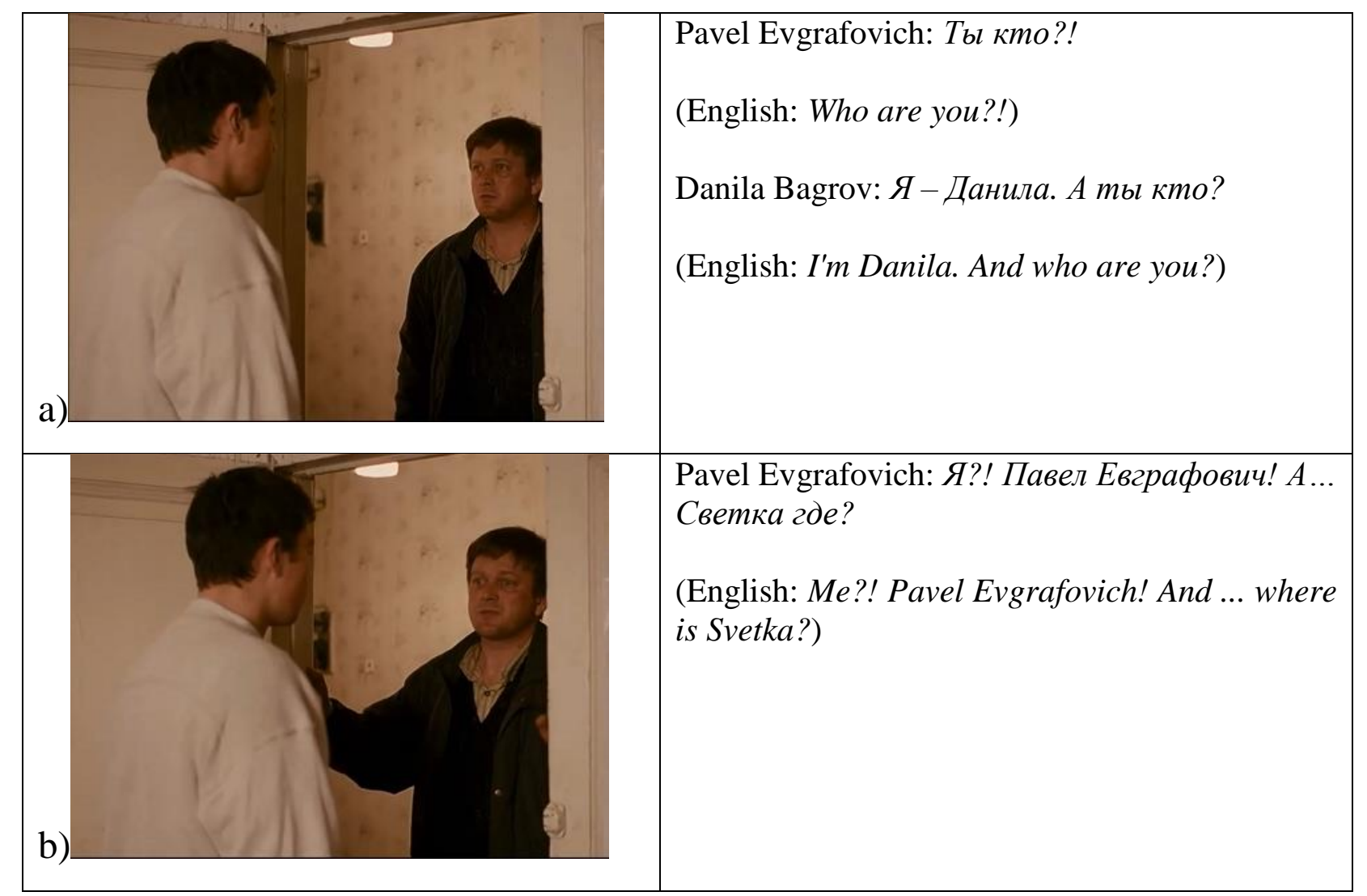




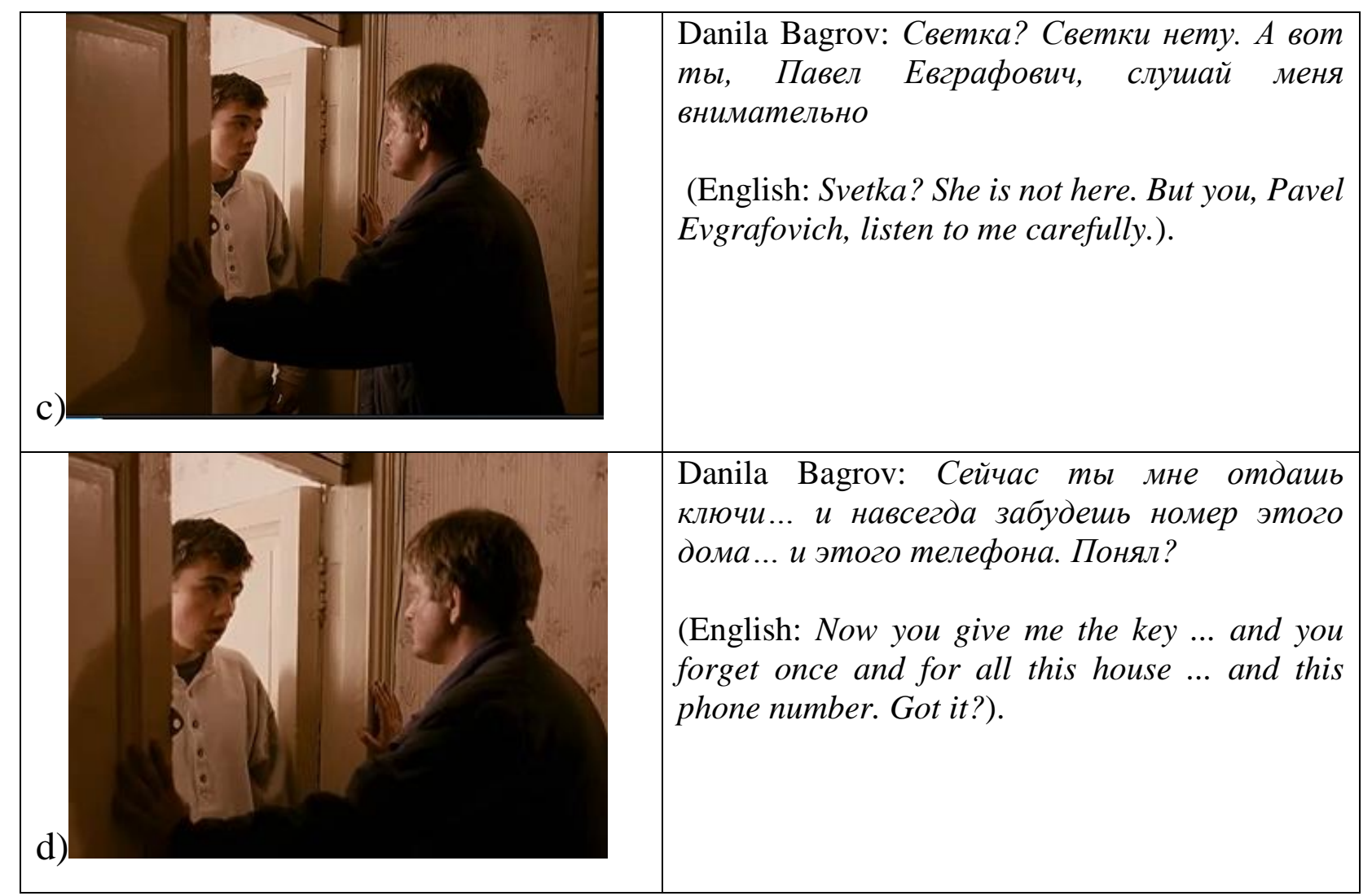

Figure 3. A direct threat with non-verbalized content elements.

Screenshots (taken by the author) from the film "The brother". Available at: https://www.youtube.com/watch? $\mathrm{v}=\mathrm{aDaaCGZz-Ok \& feature=youtu} \cdot \mathrm{be} \& \mathrm{t}=3086$

In this segment, there are no conditional sentences containing an indication of possible punitive measures following disobedience (i.e. the explicit commissive part is absent). However, the demand to leave expressed in a peremptory tone is definitely a prescriptive speech act. Moreover, the main character does not use the traditional form of the imperative mood, which gives the addressee some space for a communicative maneuver. Instead, in his utterance (in the Russian original text) he uses verbal predicates in the future tense: отдашь ключи (уоu give me the key), навсегда забудешь (уоu forget once and for all). These sentences serve as a means of expressing a rude order (Фомичева 2010: 169); at the same time, if taken out of the context, the same sentences might not be recognized as an incentive (Кубарева 1977: 74). In other words, the producer of the threat does not simply require the addressee to perform a specific action (give the keys, forget the number); he implies that the action will take 
place in the nearest future, thereby accentuating the inevitability of the actions. This imperative is emphasized by the following intonation markers:

- the confident and reserved tone of the main character, acquiring prominent aggressiveness in the last part of the speech segment (Понял? / Got it?);

- the pauses and the logical stress on meaningful words in the Russian version (Сейчас ты мне отдашь ключи... и навсегда забудешь номер этого дома... и этого телефона / Now you give me the key and forget once and for all this house and this phone number).

The combination of the linguistic (a categorical directive expressed in a sentence with verbs in the future tense) and intonation (tone, pauses, etc.) markers demonstrate the speaker's confidence that the threat will definitely be carried out by the interlocutor. At the same time, the speaker does not have any institutionally justified reasons for such confidence: Bagrov is not older than Pavel Evgrafovich, neither is he socially superior; rather the opposite is true. Moreover, legally, Bagrov has no right to give any orders to him, as he is in Pavel Evgrafovich's apartment. Therefore, the reason for Danila's confidence lies in the non-institutional sphere - his demands are backed up by the socalled 'right of force': he is younger, physically stronger, and has had military training. The aggressive message of his phrase in the context of this segment is reinforced by a number of other explicit non-verbal markers:

- the position of the speaker (he stands close enough to the interlocutor, simultaneously blocking his entrance to the room);

- the pose of the speaker (a closed pose, demonstrating his readiness to defend himself);

- the direction of the speaker's gaze (defiantly staring at the interlocutor from under his eyebrows), the corresponding incline of his head;

- the expression of the speaker's face (a cold dislike with a slight touch of contempt). 
Together, all these non-verbal markers and the verbal component of the SAT in question allow us to conclude that Pavel Evgrafovich receives a clearly aggressive signal that can be interpreted as a threat: if you do not do what I say, you will pay for that.

In a number of cases, a directive element can become an implicit (non-verbalized) part of the SAT. In our opinion, such structures are more typical of situations when the speaker wants to suppress and scare the addressee.

This is an intermediate stage of the implementation of the speaker's communicative strategy. There are still several options for the further development of events. For instance, the addressee will understand what is expected from him/her and act accordingly; or, having accepted the role of the victim, he/she will be morally ready to act in accordance with the wishes and intentions of the threat producer. The following segment (Figure 4 (Man at the window, 2009)) is a good illustration of it.

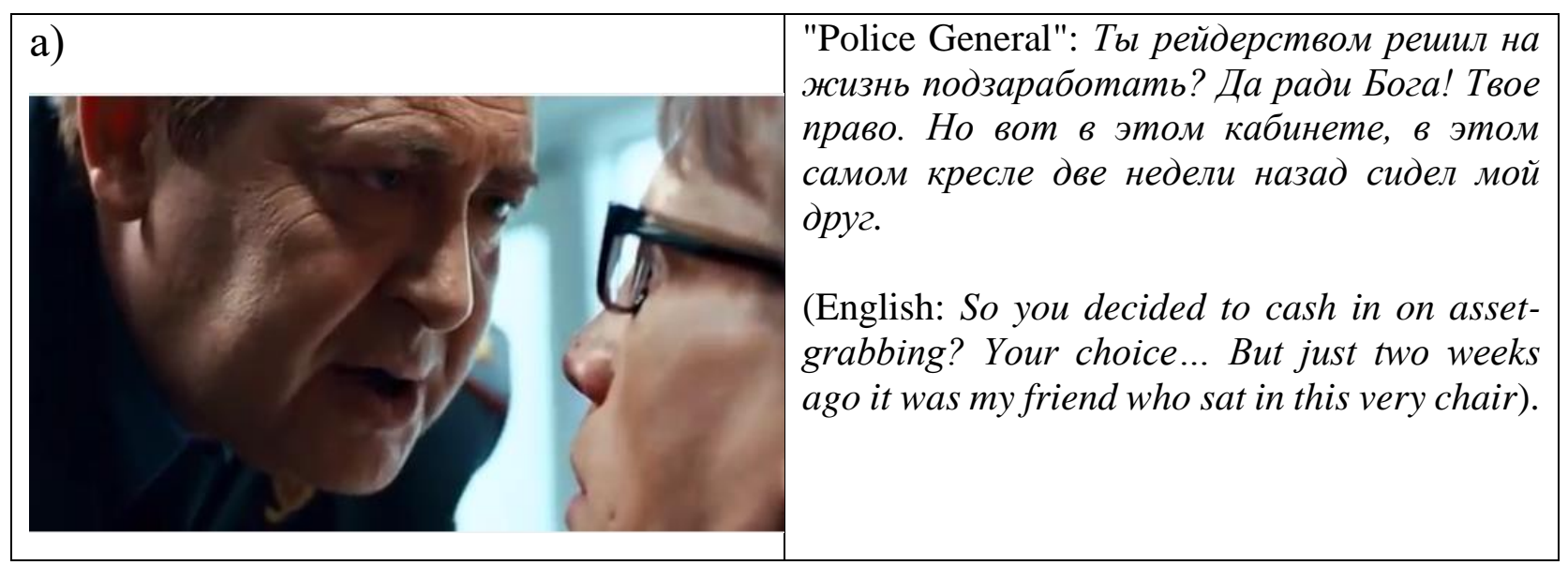




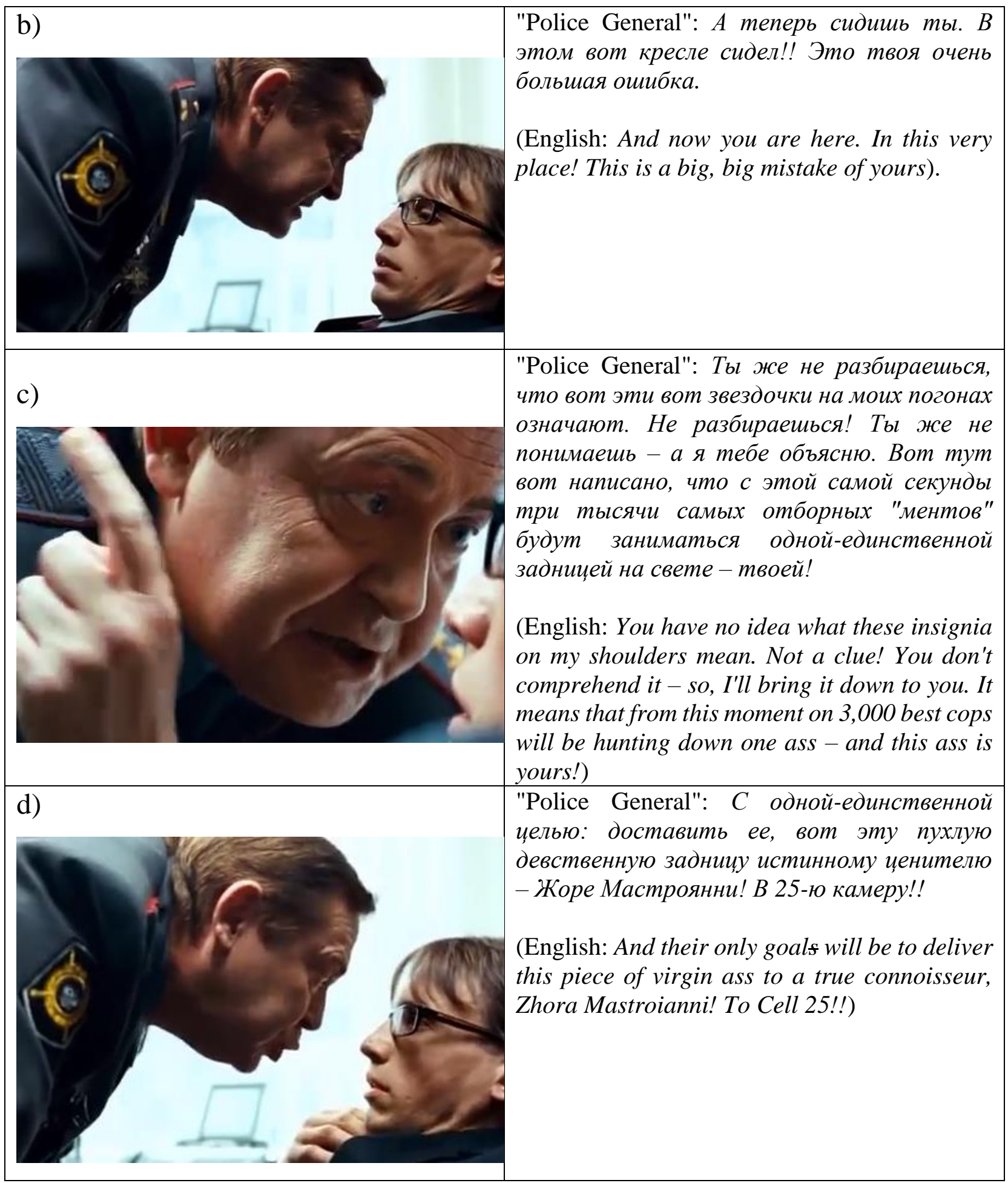

Figure 4. A direct threat with non-verbalized content elements.

Screenshots (taken by the author) from the film "The man at the window". Available at: https://www.youtube.com/watch?v=4buY-HMYhS4

This video segment shows intimidation of a director of a private company (who has occupied this position as a result of a raider seizure of this firm) by a general of the MIA of Russia who is a friend of the previous legal owner. 
Segments $c$ )-d) contain menacing promises to start a police 'hunt' for the addressee of the message, to take him into custody, and to sodomize him in prison. A number of non-verbal factors should enhance the psychological pressure produced by these words:

- the position of the interlocutors: the speaker is close to the listener, thus entering his personal space;

- the mimicry of the speaker, expressing overt hostility and aggression towards the speaker;

- the intonation of the speaker: volume of speech, ranging from a "whistling" halfwhisper to almost a scream, and its pronounced negative emotional coloration.

The implicit directive of the speech acts presented in segments $c-d$ is an implied demand to mitigate the negative consequences of the earlier act (asset-grabbing: the illicit acquisition of a business): it is indicated by the hint phrases: Вот в этом самом кресле... сидел мой друг. A теперь сидишь ты / But just two weeks ago it was my friend who sat in this very chair and Это твоя очень большая ошибка / This is a very big, big mistake of yours. As we assume, the hints, in our opinion, are aimed at the addressee's ability to draw up the following logical conclusions: There was a time when I did not raid any business - I did not have enemies in the police $\rightarrow$ I raided this business - Now I have a power enemy in the police $\rightarrow$ I will give up the gains and disappear-There will be no reason for this police officer to hate me.

The threat presented in this segment, as the film shows further, fully realizes its imperative potential (in the film, the addressee gives up the seized position in favor of the person who used to have it.). From the point of view of the victim, the speaker has both a possibility and an almost $100 \%$ chance to implement his threat (since he has the power and contacts to send the unfortunate director on a 'trip to Cell $25^{\prime}$ ). This example illustrates the importance of such a criterion of the effectiveness of the SAT as the force 
of rhetorical impact: in reality (as we know from the film), the threat producer is not a police general; he is a theatre actor, hired by a foe of the new director.

\subsection{Indirect threat}

A distinctive feature of indirect threats is that "the speaker aims to evoke fear in the addressee, but still does not express intentions to apply certain punitive measures in relation to the latter or to have them applied by third parties" (Чесноков 2015: 132). At the same time "an important point is that the addressee's actions need not be represented for the directive to be direct (and primary)" (Kissine 2013: 115).

1. The use of indirect forms of threat can be caused by the following factors: the noninstitutional nature of an act of direct threat, which is an antisocial and illegal act:

"A hierarchically organized community imposes bans on the individual's manifestation of aggression expressed both verbally and non-verbally. This, in turn, makes the individual search for non-traditional (indirect) forms of objectifying threat tactics that would allow him to implement a strategy of intimidation while formally observing ethical (and in some cases legal) social norms" (ibid.).

2. The possibility of an aggressive reaction from the addressee of a direct SAT, who may spring into offensive or violent actions; accordingly, the less clearly the threat is expressed, the slimmer the chance that the addressee will react aggressively.

3. The manifestation of moral superiority over the addressee.

In the case of an indirect threat, the addressee is formally given a choice to obey or to defy, naturally assuming responsibility for all possible negative consequences. This partially removes the responsibility of the speaker and creates additional moral pressure on the listener. For instance, imagine the situation: someone offends a woman in the street; her companion defends her and says to the offender "Either you apologize now, or I will have to deal with your upbringing". The offender does not know who the speaker is and what he can do; but, if he has uttered his threats, it is possible that he can really punish the boor (maybe, the speaker is, for example, a boxer). Therefore, the 
only way to avoid unpleasant 'surprises' in that case is to choose the 'right' option. Additionally, this, as we assume, emphasizes that the speaker is certain that he/she has all the necessary resources for implementing the threat and is ready to fulfill his/her aggressive intention in case of disobedience. In other words, the indirect form of the SAT in this case serves as an indicator of the threat producer's power and dominance over the addressee (Пробст \& Васильев 2016: 34).

4. Another motivation for using of indirect SATs, in our opinion, lies in the unwillingness of the speaker to use direct threats because it contradicts his/her philosophical and moral principles, the ideas about professionalism, etc.

According to our observations, a SAT can be classified as an indirect threat when there are no explicit linguistic or non-linguistic markers indicating its menacing character. This is manifested in the following way:

- there is no explication of the commissive component of the SAT proposition;

- the SAT does not have to be carried out (as an option, categorical directive (prescriptive) speech acts do not express causation).

Such indirect SATs can be verbalized as speech acts of other types: advice, request, proposal, etc. The non-verbal markers of aggression - facial expressions, gestures, posture, etc. - are either absent- or weakly expressed in such SATs.

A vivid illustration of an indirect threat in everyday discourse is presented in Figure 5 (Collector, 2007). A common situation is a conversation between a debt collector and a client, who has taken a bank loan. It is a telephone conversation. The collector is on the couch in his office 'pressing' his interlocutor, using the debtor's personal data from his file. 


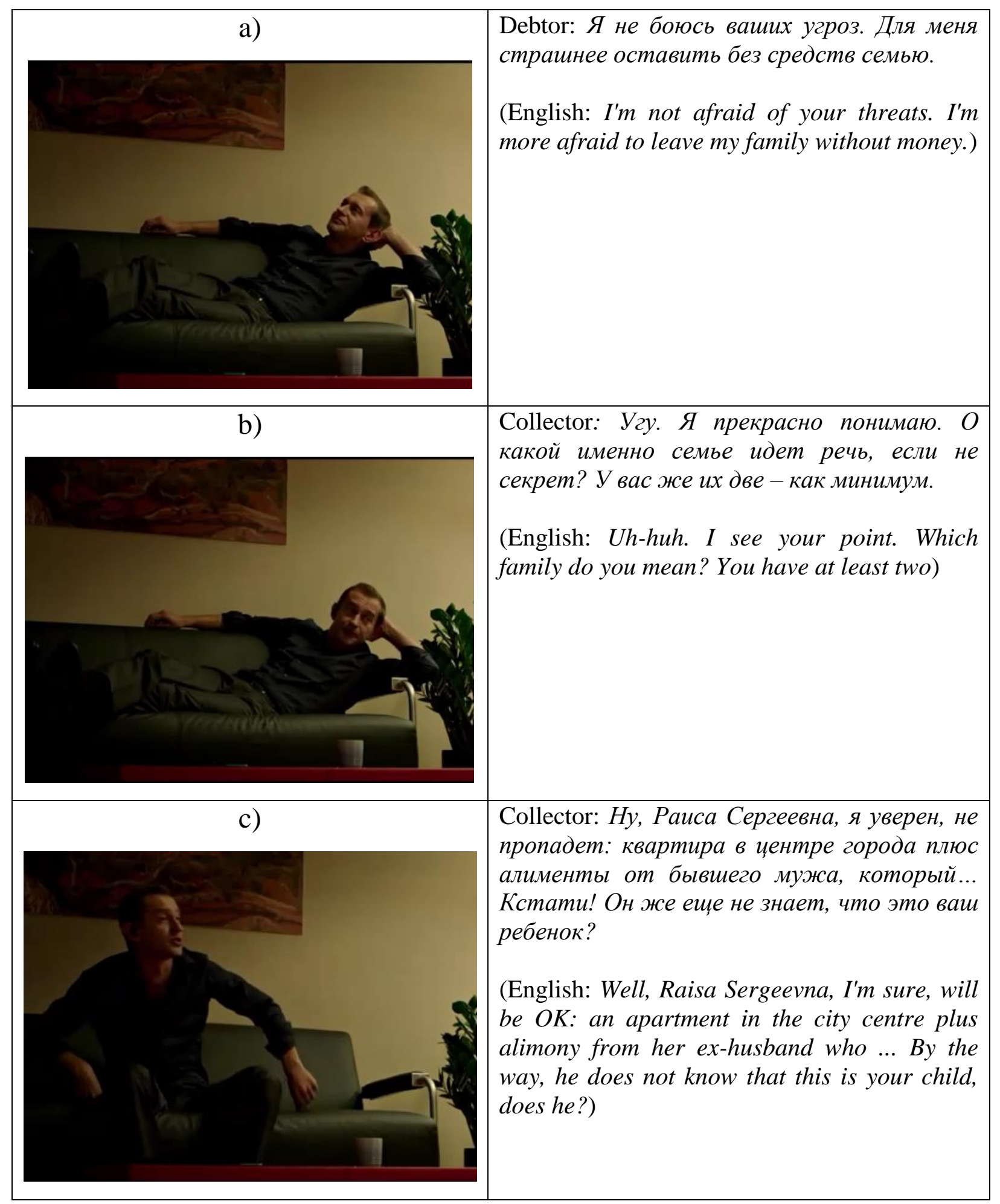




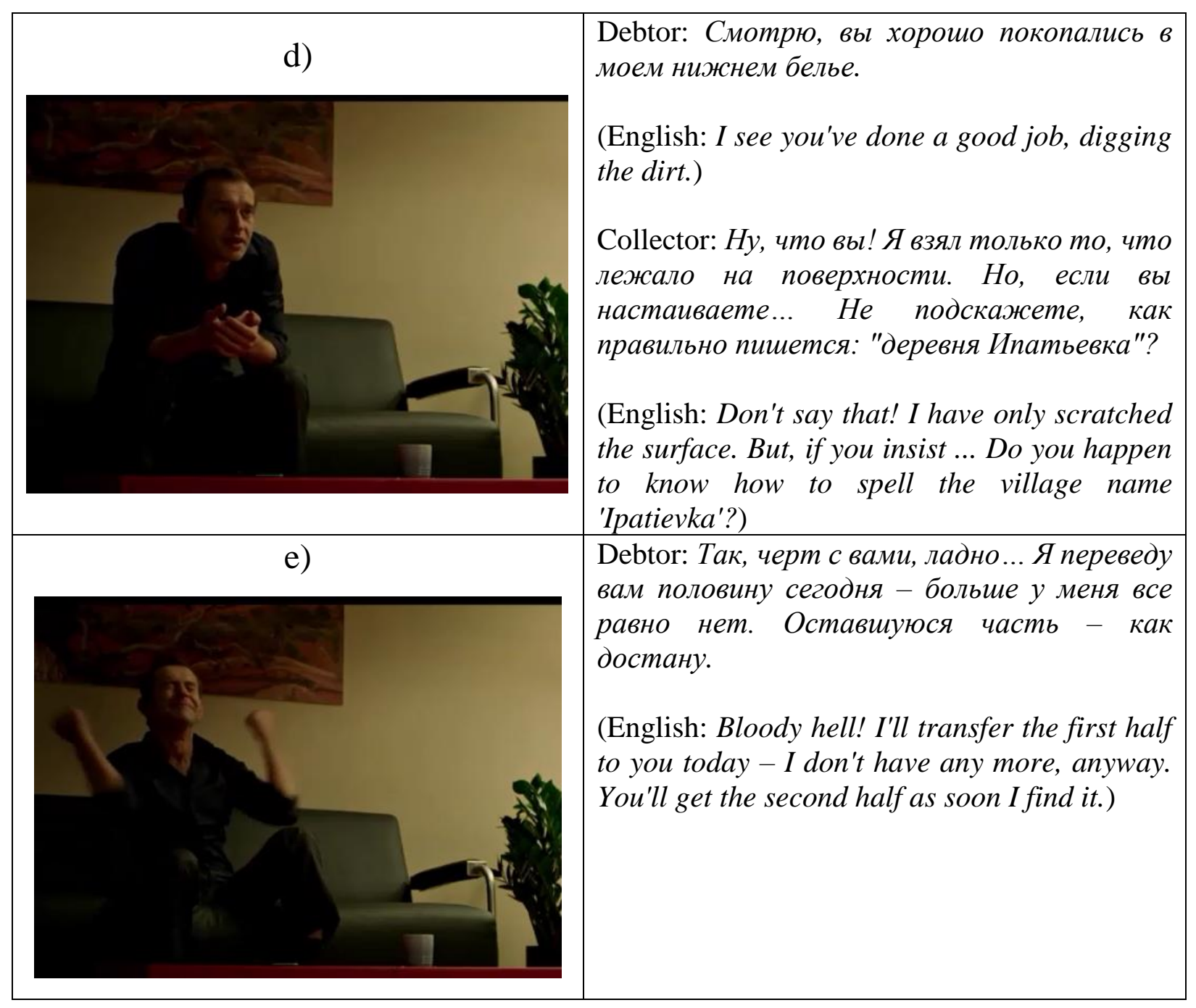

Figure 5. Indirect threat.

Screenshots (taken by the author) from the film "The thief". Available at: https://www.youtube.com/watch?v=9c0F9E-xYd4

The task of the debt collector is to impose an action, which is neither profitable, nor easy for the addressee, in order to quickly repay his debt. Traditional speech strategies of persuasion (orders, demands, advice, requests, persuasion, etc.) will not work: the debtor does not have the opportunity or the desire to pay the required sum, even being threatened by legal action. In these circumstances, the main character resorts to blackmailing. There are several factors limiting the use of the threat:

- the forced compliance with external ethical and etiquette norms of behavior, which exclude open intimidation; otherwise the debtor will either stop the conversation or turn to the police for help, which is not in the interest of the bank; 
- the possibility of an undesirable reaction to a direct threat from the addressee: judging by the addressee's voice and manner of the conversation, he is a mature confident person with strong resistance to intimidation, but easy to provoke; if pressed too hard;

- the professional self-esteem of the debt collector, which prevents him from resorting to the most primitive forms of aggressive blackmail.

The mode of conversation, on the telephone, is also important. It imposes a number of limitations: the impossibility of using any non-verbal stimuli, other than intonation; a chance of breaking the conversation by one of the interlocutors, if the talk takes an unacceptable turn for either of them; the prospect of being recorded and reported to law enforcement agencies, etc.

All these factors determine the speech behavior of the main character, who consistently voices three threats (see segments b), c), and d)).

Segment $b$. Demonstrating his awareness of the debtor's promiscuity in marriage, the collector leaves it to the debtor to assess the possible damage in case of disclosure (which the collector does not mention).

Segment $c$. Elaborating on the possible consequences of disclosure, the collector simultaneously solves two problems: 1) demonstrates his awareness of the debtor's bigamy (which increases the seriousness of the threat implied in the previous segment); 2) appeals to his fear for the well-being of his lover, Raisa Ivanovna, whose life may be ruined if the truth about her illegitimate child is revealed.

Segment $d$. The main character hints at certain circumstances connected with the village Ipatievka. Obviously, the disclosure of this information (although the collector, again, does not voice this intention directly) will be especially detrimental for the 
debtor, since the last phrase of the collector finally breaks his will to resist, and he agrees to pay half of the debt.

To sum up, the collector does not use any formal markers of threat; moreover, there are no explicators of the negative performative intention (analytical or synthetic forms of the imperative, etc.), characteristic of the Russian language. The speaker uses exclusively narrative and interrogative constructions, which outside the context of this particular situation do not have any negative performative or commissive semantics. Nevertheless, the collector achieves his aim, relying on the indirect threat to do harm to his client, which is incomparable with the financial loss, caused by the repayment of the loan even in conditions of financial instability. This example, in our view, illustrates the functioning of indirect SATs in everyday discourse.

\subsection{Direct and indirect threat in everyday conflict discourse}

A SAT is undoubtedly one of the most radical and effective types of speech acts. SATs are a means of exerting influence on the interlocutor. The discussion on the comparative effectiveness of direct and indirect forms of threat in terms of their impact on the addressee is not an easy one. On the one hand, a direct threat, according to our observations, may have the following advantages in any culture:

1. A direct threat is inherently understandable and does not require clarification - even if some part of it is expressed by non-verbal means (provided the speaker does not consider it necessary to disguise threats). Imagine the following situation: in a narrow alley, a criminal with a brick in his hand approaches a passerby in an attempt to rob him. The criminal can make his intentions clear by either shouting (i) Give me your money, or I'll put a brick in your head! or saying (ii) Will you buy this brick from me? That is for your own good. In the first case, the addressee is immediately informed of what he has to do--and what punishment he will receive for his disobedience. The second scenario allows the addressee to perceive the offer of purchasing the brick as a 
disguised money extortion and to become aware of the bodily harm that will follow should he turn down such a 'tempting' offer.

In a simplified form, the modelled process of perceiving a direct SAT is represented in Fig. 6:

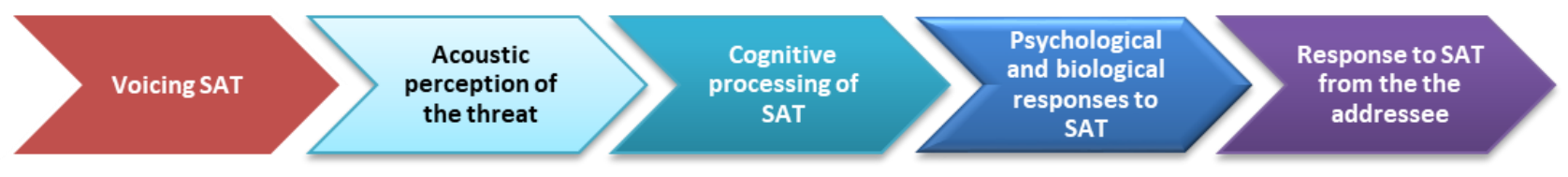

Figure 6. Process of perceiving a direct SAT

The blocks 'Voicing SAT' and 'Acoustic Perception of Threat' reflect the process of SAT production by the speaker and the perception of the SAT by the addressee. The block "Cognitive processing of SAT" is associated with the process of recognizing information as threatening by the addressee; the block "Psychological and biological responses to SAT" reflects a change in the psychological and physiological state of the addressee; "Response to SAT from the addressee" represents the final phase of the entire receptive chain - the addressee's communicative reaction to the act of threat (agreement to perform a certain action or follow a certain pattern of behavior, refusal, response aggression, etc.).

2. An indirect threat, though its effect may prove to be strong, requires more time and reasoning, than a direct SAT. To begin with, the addressee should interpret the message as a threat, "indirect speech act depends on the addressee's interpretation concerning what the speaker implies to say by his utterance" (Tsohatizidis 1994: 17). Only after that is the subsequent process of understanding the seriousness of the possible danger activated, as well as other concomitant psychological and biological effects. In a simplified form, this process can be represented as follows: 


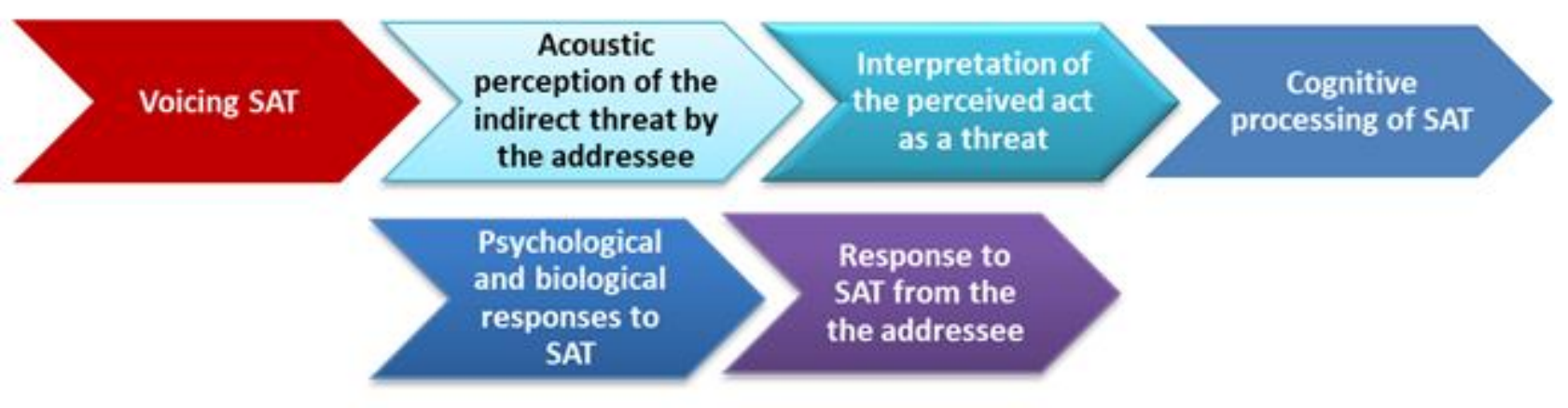

Figure 7. Process of perceiving an indirect SAT

A comparison of the two schemes shows that it takes fewer steps to realize a direct threat as opposed to a "disguised" one (see Fig. 1 and Fig. 2). Therefore, creating the short, menacing message 'Do X (causal action), or you will be Y (punished)' with a high degree of probability requires less time than an indirect threat. It leads us to the conclusion that a direct threat is easier to produce and perceive.

1. A direct threat is more typical of an informal setting. Everyday life is full of informal communication, which usually occurs between relatives, family members, friends, neighbors, co-workers, etc. In such conditions, one of the important reasons for using indirect forms of threat - its non-institutional nature - fades in comparison with other types of discourse (political, journalistic, etc.). If interlocutors talk tête-àtete, and their conversation is not recorded, or if the conversation develops in a situation when a possible negative response of the addressee can do no harm to the threat producer, an aggressively minded interlocutor has a greater degree of communicative freedom.

Taking into consideration all the aforesaid, we can conclude that clear and explicit threats are more effective in producing a menacing impact.

However, as we mentioned earlier (see section 7.3. "Indirect threat"), in cases when interlocutors have to stick to certain norms of behavior, for instance, in order to save face (formal communication, the difficulty of punishing the addressee, the speaker's 
reluctance to stir a conflict, etc.), an indirect threat is a more preferable option of directive influence.

\section{Conclusion}

A threat, as one of menacing speech acts, is an important and inherent element of conflict discourse. It is widely present in everyday communication. From the pragmalinguistic point of view, a threat is a complex speech act with a binary communicative and semantic structure. It consists of the main directive (since the main threat intention, as we prove, is to induce the addressee to a specific action, behavior, etc.) and the auxiliary commissive parts, where the commissive serves to motivate the interlocutor to perform the communication task.

From the point of view of psychological, physiological, and biopsychological factors, an act of threat activates a complex of psycho-physiological reactions associated with basic negative emotions, such as fear. The latter is caused by an imaginary or real danger for the addressee and his/her key values: life, health, his/her own well-being, and that of his/her relatives. As our research shows, interacting with the BIS, the act of threat helps to bring the addressee to a special psychological state - avoidance of danger, leading to the consent of the addressee to obey the producer of the threat.

However, we suppose that the desired communicative effect is achieved only if the act of threat meets four main success criteria: 1) possible impact of punitive measures implied in the act of threat for the addressee; 2) the possibility of execution of explicit or implicit punishment following disobedience; 3) high probability (inevitability) of threatening or implied negative consequences/actions; 4) rhetorical persuasiveness.

Like any other directive speech act, a SAT can be realized in its direct and indirect forms. Both forms perform the same communicative function. However, they differ in terms of manifestation of explicitly expressed (i.e. unambiguously understood and 
interpreted) verbal and non-verbal means of representation of its pragmasemantic components. In this regard, according to our observations, the direct threat can be conditionally divided into two types: a direct threat with verbalized content elements and a direct threat with unverbalized content elements.

An indirect threat is a speech act, in which both elements of the threat proposition are implied (there is no clearly defined commissive, and no emphasis is placed on the directive). This type of threat is usually represented by other types of speech acts requests, proposals, etc. In our opinion, resorting to indirect threats can be explained by either the unwillingness to threaten directly (which may be due to the possibility of punishment on the part of the community or another interlocutor) or by the desire of the sender to demonstrate his awareness of the current conflict situation.

It is difficult to give an unambiguous answer as to which form of threat is more prevalent in everyday conflict discourse. According to our comparative analysis, indirect threats are more difficult to express and perceive, compared to direct ones. At the same time, in formal, institutionalized discourse (or if the speaker wants to 'save face'), an indirect threat can facilitate the implementation of a manipulative intention with a lower risk of negative consequences for the speaker.

It should be noted that in the course of further research of SATs we plan to turn to other types of discourse.

\section{Notes}

Translation of movie segments from Russian into English was done by the authors.
Abbreviations
BAS - Behavioral Activation System
BIS - Behavioral Inhibition System 
SAT - Speech act of threat

Brother - a segment from the film The brother (Russian Бpam)

Collector - a segment from the film The collector (Russian Коллектор).

Man at the window - a segment from the film The man at the window (Russian Человек у окна).

Thief - a segment from the film The thief (Russian Bop).

\section{References}

Antsupov, A.J. \& Shipilov, A.I. (2000). Conflictology. Moscow: Yuniti. / Antsupov A.J., Shipilov A.I. Konfliktologia. Moskva: Yuniti. / Анцупов А.Я., Шипилов А.И. Конфликтология. Москва: Юнити.

Apresyan, V.Yu. (2003). Implicit aggression in language. In Computer linguistics and IT: Proceedings of international scientific conference "Dialogue-2003" (June, 11-16, 2003, Protvino, Russia), p. 32-35. / Apresyan V.Yu. Implitsitnaya agressiya v yazyke. In Komp'yuternaya lingvistika i intellektual'nye tekhnologii: Trudy mezhdunarodnoj konferentsii "Dialog-2003" (Iyun', 11-16, 2003, Protvino, Rossiya), s. 32-35. I Апресян В.Ю. Имплицитная агрессия в языке. In Компьютерная лингвистика $и$ интеллектуальные технологии: Труды международной конференции "Диалог2003" (Июнь, 11-16, 2003, Протвино, Россия), с. 32-35.

Austin, J.L. (1962). How to do things with words. Oxford: Oxford University Press.

Belous, N.A. (2008). Conflict discourse in the communicative space: Semantic and pragmatic aspects. Synopsis for thesis for the doctor degree in philology. Speciality 10.02.19 - theory of language. Krasnodar: Kuban state university. / Belous N.A. Konfkliktnyj diskurs $v$ kommunikativnom prostranstve: Semanticheskiye $i$ pragmaticheskiye aspekty. Avtoreferat dissertatsii na soiskaniye uchyonoj stepeni kandidata filologicheskikh nauk. Spetsial'nost' 10.02.19 - teoriya yazyka. Krasnodar: Kubanskij gosudarstvennyj universitet. / Белоус Н.А. Конфликтный дискурс в коммуникативном пространстве: Семантические и прагматические аспекты. Автореферат диссертации на соискание ученой степени доктора филологических 
наук. Специальность 10.02 .19 - теория языка. Краснодар: Кубанский государственный университет. Available at:

http://tverlingua.ru/archive/013/10_belous.pdf

Brown, P. \& Levinson, S. (2009). Politeness: Some universals in language usage. In Sociolinguistics: Critical concepts [volume III: Interactional sociolinguistics]. Jaworski, A. \& Coupland, N. (eds.). London: Routledge, p. 311-324.

Caradeux, D.A. \& Salom, L.G. (2013). Social representation of gender in awardwinner short films in Spain. In Procedia - social and behavioral sciences, 95, p. 126135.

Carver, C.S. \& White, T.L. (1994). Behavioural inhibition, behavioural activation and affective responses to impending reward and punishment: The BIS/BAS scales. In Journal of personality and social psychology, 67, p. 319-333.

Cartwright, J.P.W. (1984). An evidentiary theory of promises. In Mind, 93 (370), p. 230-248.

Chen, I.-S. \& Tseng F.-T. (2016). The relevance of communication media in conflict contexts and their effectiveness: A negotiation experiment. In Computers in human behavior, 59, p.134-141.

Chesnokov, I.I. (2015). The discoursive tactic of threat: Indirect forms of presentation: Warnings. In News of Volgograd state pedagogical university, 2 (97), p. 132-138. I Chesnokov I.I. Diskursivnaya taktika ugrozy: Kosvennye formy objektivatsii (preduprezhdeniya). In Izvestiya Volgogradskogo gosudarstvennogo pedagogicheskogo universiteta, 2 (97), s. 132-138. / Чесноков И.И. Дискурсивная тактика угрозы: Косвенные формы объективации (предупреждения). In Известия Волгоградского государственного педагогического университета, 2 (97), Волгоград, с. 132-138. Available at:

https://elibrary.ru/download/elibrary_23409431_98142983.pdf

Curseu, P.L., Boros, S. \& Oerlemans, L.A. (2012). Task and relationship conflict in short-term and long-term groups: The critical role of emotion regulation. In International journal of conflict management, 23 (1), p. 97-107. 
Dymond, S., Dunsmoor J., Vervliet, B. et al. (2015). Fear generalization in humans: Systematic review and implications for anxiety disorder research. In Behavior therapy, 46, p. 561-582.

Epshtein, O.V. (2008). Communicative and speech strategies and methods of threat realization in political discourse. In Newsletter of Orenburg state pedagogical university, 1, p. 27-33. / Epshtein O.V. Kommunikativno-rechevyye strategii i priyomy realizatsii ugrozy $\mathrm{v}$ politicheskom diskurse. In Vestnik Orenburgskogo gosudarstvennogo pedagogicheskogo universiteta, 1, s. 27-33. / Эпштейн О.В. Коммуникативно-речевые стратегии и приемы реализации угрозы в политическом дискурсе. In Вестник Оренбургского государственного педагогического университета, 1, с. 27-33.

Fedoriv, Ya. (2016). Speaking to the global audience: A case study into the message transformation. In Lege artis. Language yesterday, today, tomorrow. The journal of University of SS Cyril and Methodius in Trnava, Warsaw: De Gruyter Open, 1 (2), p. 1-36. Available at: https://www.degruyter.com/downloadpdf/j/lart.2016.1.issue-2/lart2016-0009/lart-2016-0009.pdf

Fiorelli, L. (2016). What movies show: Realism, perception and truth in film. $\mathrm{PhD}$ dissertation thesis. Available at:

https://repository.upenn.edu/cgi/viewcontent.cgi?referer=https://www.google.ru/\&htt psredir $=1 \&$ article $=3501 \&$ context $=$ edissertations

Fomicheva, E.V. (2010). Sentences with a verb in the future tense as a means of expressing motivation in the English language: A complex approach. In The almanac of modern science and education, 3 (2), p. 168-170. / Fomicheva E.V. Predlozheniya s glagolom $\mathrm{v}$ buduschem vremeni kak sredstva vyrazheniya pobuditel'nosti $\mathrm{v}$ anglijskom yazyke: Kompleksnyj podhod. In Al'manakh sovremennoj nauki i obrazovaniya, 3 (2), s. 168-170. / Фомичева Е.В. Предложения с глаголом в будущем времени как средства выражения побудительности в английском языке: Комплексный подход. In Альманах современной науки и образования, 3 (2), с. 168-170. 
Fritsche, I., Jonas, E. \& Kessler, T. (2011). Collective reactions to threat: Implications for intergroup conflict and for solving societal crises. In Social issues and policy review, 5 (1), p. 101-136. Available at:

\section{http://dx.doi.org/10.1111/j.1751-2409.2011.01027.x}

Gray, J. (1987). Neuropsychology of emotions and structure of personality. In Journal of highest nervous activity, 37 (6), p. 1011-1024. / Grej Dzh. Nejropsikhologiya i struktura lichnosti. In Zhurnal vysshej nervnoj deyatel'nosti, 37 (6), s. 1011-1024. I Грей Дж. Нейропсихология эмоций и структура личности. In Журнал высшей нервной деятельности, 37 (6), с. 1011-1024.

Greenberg, J., Martens, A., Jonas, E. et al. (2003). Psychological defense in anticipation of anxiety: Eliminating the potential for anxiety eliminates the effect of mortality salience on worldview defense. In Psychological science, 14 (5), p. 516-519. Available at: http://dx.doi.org/10.1111/1467-9280.03454.

Jing-Schmidt, Z. \& Kapatsinski, V. (2012). The apprehensive: Fear as endophoric evidence and its pragmatics in English, Mandarin, and Russian. In Journal of pragmatics, 44 (4), p. 346-373.

Jonas, E., McGregor, I., Klackl, J. et al. (2014). Threat and defense: From anxiety to approach advances. In Experimental social psychology, 49, p. 219-286.

Karasik, V.I. (2000). On the types of discourse. In Linguistic personality: Institutional and personal discourse. Karasik V.I. \& Slyshkin G.G. (eds.). Volgograd: Volgograd state pedagogical university press, p. 5-20. / Karasik V.I. O tipakh diskursa. In Yazykovaya lichnost': Institutsional'nyj i personal'nyj diskurs. Karasik V.I. \& Slyshkin G.G. (red.). Volgograd: Izdatel'stvo Volgogradskogo gosudarstvennogo pedagogicheskogo universiteta, s. 5-20. / Карасик В.И. О типах дискурса. In Языковая личность: Институциональный и персональный дискурс. Карасик В.И. \& Слышкин Г.Г. (ред.). Волгоград: Издательство Волгоградского государственного педагогического университета, с. 5-20.

Karaziya, N.A. (2006). Pragmatic research of conflict discourse. In Newsletter of Kamchatka regional association "Scientific-educational centre". Humanitarian 
sciences, 2, p. 72-88. / Karaziya N.A. Lingvopragmaticheskoye issledovaniye konfliktnogo diskursa. In Vestnik Kamchatskoj regional'noj assotsiatsii "Uchebnonauchnyj tsentr". Gumanitarnyye nauki, 2, s. 72-88. / Каразия Н.A. Лингвопрагматическое исследование конфликтного дискурса. In Вестник Камчатской региональной ассоциащии "Учебно-научный центр". Гуманитарные науки, 2, с. 72-88.

Kaushal, R. \& Kwantes, C.T. (2006). The role of culture and personality in choice of conflict management strategy. In International journal of intercultural relations, $30, \mathrm{p}$. 579-603.

Kissine, M. (2013). From utterances to speech acts. New York: Cambridge University Press.

Kozloff, S. (2000). Overhearing film dialogue. Oakland: University of California Press, Berkeley.

Kubareva, E.E. (1977). Explicit and implicit performative constructions in English (in comparison with Russian). In Comparative linguistic analysis, 202, p. 3-80. / Kubareva E.E. Eksplitsitnyye i implitsitnyye pobuditel'nyye konstruktsii v anglijskom yazyke (v sopostavlenii s russkim). In Sopostavitel'nyj lingvisticheskij analiz, 202, s. 3-80. I Кубарева Е.Е. Эксплицитные и имплицитные побудительные конструкции в английском языке (в сопоставлении с русским). In Сопоставительнылй лингвистический анализ, 202, с. 3-80.

Leech, G.N. (1983). Principles of pragmatics. London: Longman.

Limberg, H. (2009). Impoliteness and threat responses. In Journal of pragmatics, 41, p. 1376-1394.

McGregor, I., Nash, K., Mann, N. et al. (2010). Anxious uncertainty and reactive approach-motivation (RAM). In Journal of personality and social psychology, 99 (1), p. $133-147$.

Martynova, I.A. (2006). Functional and pragmatic field of menacive speech acts. Synopsis for thesis for the candidate degree in philology. Speciality $10.02 .04-$ Germanic languages. Samara: Samara state pedagogical university. / Martynova I.A. 
Funktsional'no-pragmaticheskoye pole menasivnykh rechevykh aktov. Avtoreferat dissertatsii na soiskaniye uchyonoj stepeni kandidata filologicheskikh nauk. Spetsial'nost' 10.02 .04 - germanskiye yazyki. Samara: Samarskij gosudarstvennyj pedagogicheskij universitet. / Мартынова И.А. Функиионально-прагматическое поле менасивных речевых актов. Автореферат диссертации на соискание ученой степени кандидата филологических наук. Специальность 10.02.04 - германские языки. Самара: Самарский государственный педагогический университет.

Maslova, A.Yu. (2007). Introduction to pragmalinguistics. Moscow: Flinta: Nauka. I Maslova A.Yu. Vvedeniye v pragmalingvistiku. Moskva: Flinta: Nauka. / Маслова А.Ю. Введение в прагмалингвистику. Москва: Флинта: Наука.

Mehrabian, A. (1968). Communication without words. In Psychology today, 2 (4), p. 53-56.

Mehrabian, A. \& Wiener, M. (1967). Decoding of inconsistent communications. In Journal of personality and social psychology, 6, p. 108-114.

Nicoloff, F. (1989). Threats and illocutions. In Journal of pragmatics, 113, p. 501-522. Novoselova, O.V. (2013). Functional and semantic characteristics of discursive practices with the meaning of threat in the English language. Synopsis for thesis for the candidate degree in philology. Speciality 10.02.04 - Germanic languages. Tver': Tver' state university. / Novosyolova O.V. Funktsional'no-semanticheskaya kharakteristika diskursivnykh praktik so znacheniyem ugrozy v anglijskom yazyke. Avtoreferat dissertatsii na soiskaniye uchyonoj stepeni kandidata filologicheskikh nauk. Spetsial'nost' 10.02.04 - germanskiye yazyki. Tver': Tverskoj gosudarstvennyj universitet. / Новоселова О.В. Функционально-семантическая характеристика дискурсивных практик со значением угрозы в английском языке. Автореферат диссертации на соискание ученой степени кандидата филологических наук. Специальность 10.02.04 - германские языки. Тверь: Тверской государственный университет. 
Novoselova, O., Romanov, A. \& Romanova, L. (2015). Communicative construct of the composite threat-performatives. In Procedia-social and behavioral sciences, 206, p. 71-75.

Ohm, E. \& Thompson, V. (2004). Everyday reasoning with inducements and advice. In Thinking \& reasoning, 10 (3), p. 241-272.

Perelmutter, R. (2018). Globalization, conflict discourse, and Jewish identity in an Israeli Russian-speaking online community. In Journal of pragmatics (article in press). Piazza, R. (2006). The representation of conflict in the discourse of Italian melodrama. In Journal of pragmatics, 38 (12), p. 2087-2104.

Pocheptsov, G.G. (2001). Theory of communication. Moscow: Refl-buk. / Pocheptsov G.G. Teoriya kommunikatsii. Moskva: Refl-buk. / Почепцов Г.Г. Теория коммуникации. Москва: Рефл-бук.

Probst, N.A. \& Vasilyev, S.L. (2016). Functional and semantic aspects of threat in requestive speech acts (based on the Soviet and Russian feature films). In Newsletter of Immanuel Kant Baltic federal university. Philology, pedagogy, psychology, 4, p. 2834. / Probst N.A., Vasil'yev S.L. Funktsional'no-semanticheskiye osobennosti ugrozy rekvestivnogo tipa (na materiale sovetskikh i rossijskikh khudozhestvennykh fil'mov). In Vestnik Baltijskogo federal'nogo universiteta imeni Immanuila Kanta. Filologiya, pedagogika, psikhologiya, 4, s. 28-34. / Пробст Н.А., Васильев С.Л. Функционально-семантические особенности угрозы реквестивного типа (на материале советских и российских художественных фильмов). In Вестник Балтийского федерального университета имени Иммануила Канта. Филология, педагогика, психология, 4, с. 28-34.

Rahim, M.A. (2015). Managing conflict in organizations. New Brunswick: Transaction Publishers.

Romanov, A.A. (1988). System analysis of regulative means of dialogue interaction. Moscow: The Institute of linguistics of the Academy of Sciences of USSR. / Romanov A.A. Sistemnyj analiz regulyativnykh sredstv dialogicheskogo obshcheniya. Moskva: Institut yazykoznaniya Akademii nauk SSSR. / Романов A.A. Системный анализ 
регулятивных средств диалогического общения. Москва: Институт языкознания AH CCCP.

Romanova, L.A. (2009). Structural and semantic aspects of the performatives in the functional paradigm of the language. Moscow-Tver': The Institute of linguistics of the Russian Academy of Sciences. / Romanova L.A. Strukturno-semanticheskiye aspekty performativov v funktsional'noj paradigme jazyka. Moskva-Tver': Institut lingvistiki Rossijskoj akademii nauk. / Романова Л.А. Структурно-семантические аспекты композитных перформативов в функииональной парадигме языка. МоскваТверь: Институт лингвистики Российской академии наук.

Rubin, J., Pruitt, D. \& Kim, S.H. (2001). Social conflict: Escalation, impasse, resolution. St. Petersburg: Prajm-Evroznak. / Rubin Dzh., Prujtt D. \& Kim S.Kh. Sotsial'nyj konflikt: Eskalatsiya, tupik, razresheniye. Sankt-Peterburg: PrajmEvroznak. / Рубин Дж., Пруйт Д. \& Ким С.Х. Социальный конфликт: Эскалация, тупик, разрешение. Санкт-Петербург: Прайм-Еврознак.

Sadykova, I.A. (2016). Ethno-speech taboos in conflict discourse. In Philology \& culture, 2 (44), p. 122-125. / Sadykova I.A. Etnorechevyye zaprety v structure konfliktnogo diskursa. In Filologiya i kultura, 2 (44), s. 122-125. / Садыкова И.А. Этноречевые запреты в структуре конфликтного дискурса. In Филология $u$ культура, 2 (44), с. 122-125.

Salgueiro, A.B. (2010). Promises, threats, and the foundations of speech act theory. In Pragmatics, 20 (2), p. 213-228. Available at:

https://journals.linguisticsociety.org/elanguage/pragmatics/article/download/2569/25 69-5290-1-PB.pdf

Sami, S. (2015). The differences between threat and promise acts. In International research journal of humanities \& social science, 1 (3), p. 46-53.

Searle, J.R. (1969). Speech acts: An essay in the philosophy of language. Cambridge: Cambridge University Press.

Searle, J.R. (1975). A taxonomy of illocutionary acts. In Language, mind and knowledge, 7, p. 344-369. Available at: 


\section{https://conservancy.umn.edu/handle/11299/185220}

Searle, J.R. (1979). Expression and meaning. Cambridge: Cambridge University Press. Seyranyan, M.Yu. (2016). Conflict discourse and its prosodic structure. Moscow: Moscow city pedagogical university press. / Seyranyan M.Yu. Konfliktnyj diskurs $i$ yego prosodicheskij stroj. Moskva: Izdatel'stvo Moskovskogo gorodskogo pedagogicheskogo universiteta. / Сейранян М.Ю. Конфликтный дискурс и его просодчческий строй. Москва: Издательство Московского городского педагогического университета.

Scherbatykh, Yu.V. \& Nozdrachev, A.D. (2000). Physiology and psychology of fear. In Nature, 5, p. 61-67. / Scherbatykh Yu.V., Nozdrachev A.D. Fiziologiya i psikhologiya strakha. In Priroda, 5, s. 61-67. / Щербатых Ю.В., Ноздрачев А.Д. Физиология и психология страха. In Природа, 5, с. 61-67. Available at: http://in.1543.ru/VIVOVOCO/VV/JOURNAL/NATURE/05_00/05_61-67.HTM

Shkapenko, T.M. \& Vertelova, I.Yu. (2018). Markers of hostility speech in Internet comments to the translated articles in the Polish media. In Political linguistics, 40 (70), p. 104-111. / Shkapenko, T.M., Vertelova, I.Yu. Markery yazyka vrazhdy v internetkommentariyah k perevodnym stat'yam pol'skikh SMI. In Politicheskaya lingvistika, 40 (70), s. 104-111. / Шкапенко Т.М., Вертелова И.Ю. Маркеры языка вражды в интернет-комментариях к переводным статьям польских СМИ. In Политическая лингвистика, 40 (70), с. 104-111.

Smith, D. (1997). Language and discourse in conflict and conflict resolution. In Current issues in language and society, 4 (3), p. 190-214.

Tsohatzidis, S.L. (1994). Foundation of speech act theory: Philosophical and linguistic perspectives. London: Taylor and Francis.

Van den Bos, K. \& Miedema, J. (2000). Toward understanding why fairness matters:

The influence of mortality salience on reactions to procedural fairness. In Journal of personality and social psychology, 79 (3), p. 355-366.

Vendler, Z. (1985). Illocutionary suicide. In New in foreign linguistics, 16, p. 238-251. / Vendler Z. Illokutivnoye samoubijstvo. In Novoye v zarubezhnoj lingvistike, 16, s. 
238-251. / Вендлер 3. Иллокутивное самоубийство. In Новое в зарубежной лингвистике, 16, с. 238-251.

Wierzbicka, A. (1985). The speech acts. In New in foreign linguistics, 16, p. 43-65. I Werzbitska A. Rechevyye akty. In Novoye v zarubezhnoj lingvistike, 16, s. 43-65. I Вежбицка А. Речевые акты. In Новое в зарубежной лингвистике, 16, с. 43-65. Wunderlich, D. (1976). Studien zur Sprechakttheorie. Frankfurt am Main: Suhrkamp. Zamfir, M.V. (2017). Verbal and non-verbal communication in sport environment. In Marathon, 9 (1), p. 99-106.

Zhuchkov, D.O. (2009). On defining and classifying the speech act of threat. In Newsletter of Voronezh state university. Linguistics and intercultural communication, 2, p. 69-71. / Zhuchkov D.O. K voprosu ob opredelenii i klassifikatsionnoj prinadlezhnosti rechevogo akta ugrozy. In Vestnik Voronezhskogo gosudarstvennogo universiteta. Lingvistika i mezhkul'turnaya kommunikatsiya, 2, s. 69-71. / Жучков Д.О. К вопросу об определении и классификационной принадлежности речевого акта угрозы. In Вестник Воронежского государственного университета. Лингвистика и межкультурная коммуникачия, 2, с. 69-71.

Zhuchkov, D.O. (2010). Speech act of threat as an object of pragmalinguistic analysis (on the material of the English language). Synopsis for thesis for the candidate degree in philology. Speciality 10.02.04 - Germanic languages. Voronezh: Voronezh state university. / Zhuchkov D.O. Rechevoj akt ugrozy kak obyekt pragmalingvisticheskogo analiza (na materiale anglijskogo yazyka). Avtoreferat dissertatsii na soiskaniye uchyonoj stepeni kandidata filologicheskikh nauk. Spetsial'nost' 10.02.04 germanskiye yazyki. Voronezh: Voronezhskij gosudarstvennyj universitet. / Жучков Д.О. Речевой акт угрозы как объект прагмалингвистического анализа (на материале английского языка). Автореферат диссертации на соискание ученой степени кандидата филологических наук. Специальность 10.02.04 - германские языки. Воронеж: Воронежский государственный университет. 


\section{Examples from the films}

The brother. (1997) [a segment of the film]. Director: Balabanov, A. Starring: Bodrovjr., S. Russia: STV. Available at: https://www.youtube.com/watch?v=aDaaCGZz$\underline{\text { Ok} \& \text { feature }=\text { youtu } \cdot \text { be } \& \mathrm{t}=30856 \& \text { end }=3112}$

The collector. (2017). [a segment of the film]. Director: Krasovskiy, A. Starring:

Khabenskiy, K. Russia: All Media. Available at:

https://www.youtube.com/watch?v=9c0F9E-xYd4

The man at the window. (2009). [a segment of the film]. Director: Meskhiev, D.

Starring: Stoyanov, Yu. Russia: Flagman-Trade. Available at:

https://www.youtube.com/watch?v=4buY-HMYhS4

The thief. (1997). [a segment of the film]. Director: Chukhray, P. Starring: Mashkov,

V. Russia-France: NTV-Profit. Available at:

https://www.youtube.com/watch?v=1MGvFJkME7c

\begin{tabular}{|c|c|}
\hline \begin{tabular}{l}
\multicolumn{1}{c}{ Contact data } \\
Nikita Probst, \\
CSc., (Philology), \\
Associate Professor, \\
Institute of Humanities, \\
Immanuel Kant Baltic \\
Federal University \\
56a, Chernyshevsky str., \\
Kaliningrad, 236000, \\
Russia e-mail: \\
NProbst@ kantiana.ru
\end{tabular} & $\begin{array}{l}\text { Psycholinguistics, theory } \\
\text { of communication, } \\
\text { discourse studies, } \\
\text { modality }\end{array}$ \\
\hline \begin{tabular}{l}
\multicolumn{1}{c}{ Contact data } \\
\multicolumn{1}{c}{ Tatiana Shkapenko, } \\
DSc. (Philology), \\
Associate Professor \\
Immanuel Kant Baltic \\
Federal University \\
56a, Chernyshevsky str., \\
Kaliningrad, 236000, \\
Russia e-mail: \\
TShkapenko@kantiana.ru
\end{tabular} & $\begin{array}{l}\text { Pragmalinguistics, } \\
\text { linguistic globalization, } \\
\text { Internet communication, } \\
\text { social semiotics }\end{array}$ \\
\hline
\end{tabular}




\begin{tabular}{|l|l|}
\hline \multicolumn{1}{|c|}{ Contact data } \\
Arina Tkachenko, \\
CSc., (Philology), \\
Associate Professor, \\
Institute for the Humani- \\
ties Immanuel Kant Baltic \\
Federal University \\
56a, Tchernyshevsky str., \\
Kaliningrad, 236000, Rus- \\
sia e-mail: \\
atkachenko@kantiana.ru
\end{tabular}

\section{Résumé}

The authors perform a pragmasemantic analysis of the speech act of threat (SAT) in everyday conflict discourse. Special attention is paid to pragmalinguistic, biopsychological, communicative, and semantic effects of direct and indirect threats. Employing methods of linguistic research, the authors describe the main peculiarities of the use of direct and indirect forms of threat in everyday discourse, using segments of Russian feature films as examples. The authors define the speech act of threat as a complex speech act with a binary semantic structure, including the main directive part and the auxiliary commissive part. The data received from biopsychology show that a SAT activates the emotional state of fear, thus affecting the addressee both at the psychological and physiological levels. The authors also identify four main success criteria, common for direct and indirect forms of threat. A detailed analysis of the examples, illustrating the SAT functioning, proves the significance of non-verbal 
expression of these acts. According to the research, direct threats can be divided into two types: a direct threat with verbalized content elements and a direct threat with nonverbalized content elements. If both elements of the threat proposition are implied, this serves as a marker of an indirect threat, represented by other speech acts. The researchers' analysis has shown that the communicative effectiveness of an indirect form of threat can be as high as that of a direct one. In the context of everyday conflict discourse, direct threats tend to occur more frequently due to their simplicity and effectiveness. However, in cases where the communication environment imposes certain limits on the communicants (the need to observe etiquette, the possibility of negative consequences for the speaker, etc.), an indirect threat may be more preferable.

Keywords: pragmalinguistics, theory of speech acts, speech act of threat, directive speech act, commissive speech act.

Article was received by the editorial board 23.05.18;

Reviewed 17.08.18. and 18.08.18.

Similarity Index 4\% 